\title{
KELAYAKAN MEDIA BUKU BERGAMBAR BERBASIS VISUAL THINKING STRATEGIES DI SEKOLAH DASAR
}

\author{
Sutama (1) \\ Universitas Muhammadiyah Surakarta \\ Sutama@ums.ac.id \\ Meggy Novitasari (2) \\ Universitas Muhammadiyah Surakarta \\ meggy151013@gmail.com \\ Nur Asih Wulandari (3) \\ Universitas Muhammadiyah Surakarta \\ Nurasihwulandari95@gmail.com \\ Anam Sutopo (4) \\ Universitas Muhammadiyah Surakarta \\ Anam.Sutopo@ums.ac.id \\ Sabar Narimo (5) \\ Universitas Muhammadiyah Surakarta \\ sabar.narimo@ums.ac.id
}

DOI: 10.23917/varidika.v32i2.12855

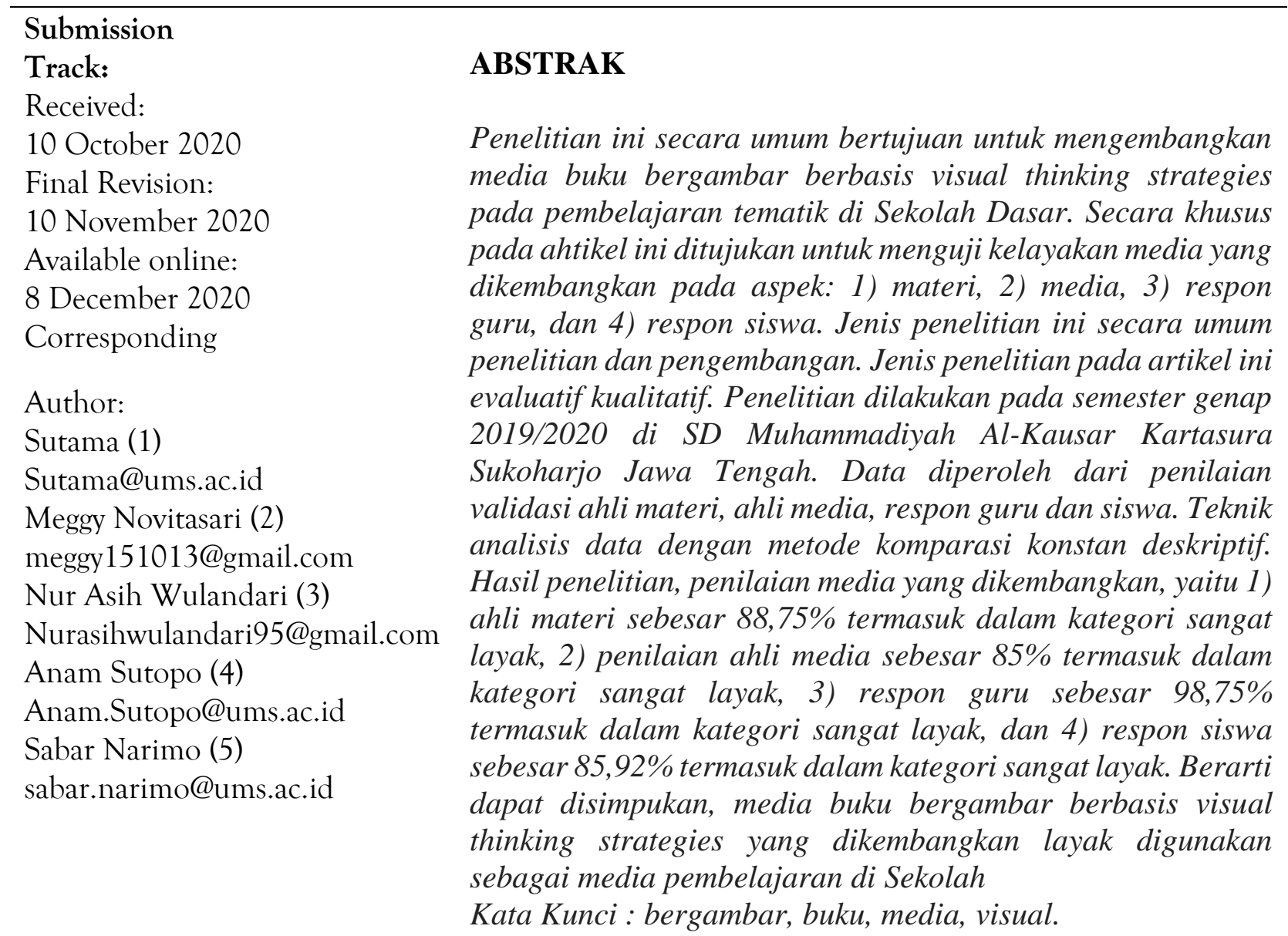




\section{PENDAHULUAN}

Teknologi informasi dan komunikasi saat ini berkembang sangat pesat. Pengaruh perkembangan teknologi membawa dampak ke berbagai aspek kehidupan, tak terkecuali dalam bidang pendidikan. Menurut Muhson (2010) kemajuan teknologi dalam bidang pendidikan berdampak pada penggunaan alat-alat bantu mengajar di sekolah sehingga melalui perkembangan teknologi dan informasi pembelajaran akan menjadi lebih efektif dan efisien.

Dampak perkembangan teknologi telah menjamah di berbagai kalangan termasuk para remaja bahkan anak-anak. Terbukti dari 32 siswa Sekolah Dasar (SD) tempat penelitian sebagian besar memiliki smartphone. Kemajuan teknologi juga memberikan kemudahan bagi siswa untuk mendapatkan informasi apa saja, kapan saja, dimana saja, dengan siapa saja dan dengan cara apa saja. Hal ini tentunya menjadi tantangan baru bagi pembelajaran, khususnta dalam pengaturan waktu (Retnawati,et al., 2017).

Saat ini sistem pendidikan di Indonesia menggunakan Kurikulum 2013 Revisi. Terdapat empat cakupan aspek penilaian yaitu (1) aspek spiritual, (2) aspeksosial, (3) aspek pengetahuan, dan (4) aspek ketrampilan. Pelaksanaan pembelajaran kurikulum 2013 Revisi mengharuskan siswa lebih kreatif dan inovatif dalam pembelajaran menggunakan media yang menarik(Burdina, Krapotkina, \& Nasyrova, 2019).

Kreativitas dan inovatif dalam pembelajaran diperlukan sarana media untuk menunjangnya, terutama usia siswa Sekolah Dasar. Media merupakan alat yang dapat digunakan sebagai perantara dalam menstimulasi semua aspek perkembangan pada siswa baik aspek nilai moral dan agama, aspek fisik motorik, aspek bahasa, aspek sosial emosional, aspek kognitif maupun aspek seni. Hal ini menunjukkan bahawa media memiliki peran penting.

Pengembangan media buku bergambar berbais Visual Thinking Strategies (VTS) merupakan aktualisasi media buku bergambar yang diaplikasikan melalui strategi pembelajaran berpikir visual. Pengembangan media ini dapat digunakan sebagai alternatif guru dalam meningkatkan ketrampilan abad 21. Visual thinking adalah proses intelektual intuitif dan ide imajinasi visual dalam pencitraan mental melalui gambar (Yenawine, 2013). Berpikir visual ini mengacu pada salah satu aspek ketrampilan abad 21 yang harus dimiliki siswa.

Penggunaaan media buku berbasis VTS mendorong pemikiran yang aktif dan proses analitis untuk memahami, menafsirkan, dan memproduksi pesan visual. Media ini merupakan sarana interaksi antara melihat, membayangkan, dan menggambarkan (berpikir verbal). Melalui media buku bergambar siswa berkolaborasi dengan teman satu kelompok untuk memecahkan 
permasalah. Pembelajaran menggunakan media buku bergambar dapat membantu peningkatan kemampuan siswa. Hal ini menjadikan penting untuk melakukan pengembangan media buku bergambar berbasis VTS.

Media buku bergambar berbasis VTS menekankan pembentukan kreativitas, pemberian sejumlah kegiatan, suasana yang alamiah, dan memperhatikan pengalaman siswa. Media ini melihat pengalaman langsung siswa sebagai kunci dalam pembelajaran dan mempermudah gusru sebagai fasilitator (Mustika, 2015). Siswa mengkonstruksi pengetahuannya melalui interaksi dengan objek, fenomena, pengalaman dan lingkungannya. Pembelajaran tematik dengan media buku bergambar ini melihat siswa dari segi keunikan/kekhasannya, potensinya, dan motivasi yang dimilikinya.

Proses pembelajaran tematik dengan media buku bergambar berbasis VTS akan membuat pembelajaran kondusif. Implementasinya dalam pembelajaran, yaitu 1) siswa mengidentifikasi masalah dan hubungan timbal baliknya, dengan aktivitas melihat dan mengumpulkan, 2) siswa memahami masalah dan kesempatan, dengan aktivitas menyeleksi dan mengelompokkan, 3) siswa mengeneralisasikan langkah untuk menemukan solusi, dengan kegiatan pengenalan pola, dan 4) siswa menjelaskan apa yang dilihat dan diperoleh kemudian dikomunikasikannya (Lestari \& Khaeriyah, 2018).

Pengembangan media buku bergambar berbasis VTS merupakan salah satu bentuk pengembangan media yang diaplikasikan melalui strategi pembelajaran visual thinking. Kemampuan visual thinking perlu dilatihkan kepada siswa karena jika siswa memiliki kemampuan berpikir visual, siswa akan dapat aktif merepresentasi gambaran pemikiran dalam benaknya, sehingga dapat memecahkan masalah pembelajaran di sekolah dan masalah yang dihadapi dalam kehidupan sehari-hari.

Penelitian ini secara umum bertujuan untuk mengembangkan media buku bergambar berbasis visual thinking strategies pada pembelajaran tematik di Sekolah Dasar. Secara khusus pada artikel ini ditujukan untuk menguji kelayakan media yang dikembangkan pada aspek: 1) materi, 2) media, 3) respon guru, dan 4) respon siswa.

\section{METODE}

Jenis penelitian ini secara umum penelitian dan pengembangan. Tahapan pengembangannya yaitu, 1) analisis kebutuhan (studi pustakan dan survei lapangan, serta penyusunan draf produk), 2) pengembangan (ujicoba terbatas dan uji coba lebih luas), dan 3) 
pengujian produk secara empiris. Jenis penelitian pada artikel ini evaluatif kualitatif deskriptif (Sutama, 2019). Penelitian dilaksanakan di SD Muhammadiyah Al-Kausar Kartasura Sukoharjo Jawa Tengah. Waktu penelitian semester genap 2019/2020 dari bulan bulan Januari sampai bulan Agustus 2020.

Subjek penelitian ini siswa kelas 3A SD Muhammadiyah Al-Kausar Kartasura Sukoharjo Jawa Tengah sebanyak 28 siswa. Sedangkan objek dari penelitian ini media buku bergambar berbasis VTS.

Data diperoleh dari penilaian validasi ahli materi, ahli media, respon guru dan siswa. Sebelum instrumen digunakan untuk menilai media yang dikembang, dilakukan uji validitas dan uji reliabilitas. Menurut Sugiyono (2012) uji validitas dimaksudkan untuk menguji derajat ketepatan atau dapat mengukur apa yang seharusnya diukur. Sedangkan uji reliabilitas dilakukan untuk mengukur derajat konsistensi dan kestabilan data.

Uji validitas dilakukan pada setiap iten instrumen. Uji validitas dilakukan dengan menggunakan rumus korelasi product moment.

$$
r_{x y}=\frac{\mathrm{N} \sum x y-\left(\sum x\right)\left(\sum y\right)}{\sqrt{\left(N \sum x^{2}-\left(\sum x^{2}\right)\left(N \sum y^{2}-\sum y^{2}\right)\right.}}
$$
Keterangan:
$r_{x y} \quad:$ Korelasi antara variabel $\mathrm{x}$ dan $\mathrm{y}$
$\mathrm{N} \quad$ : Banyaknya pasangan data $\mathrm{x}$ dan data $\mathrm{y}$
$\sum x \quad$ : Total jumlah dari variabel $\mathrm{x}$
$\sum y \quad$ : Total jumlah dari variabel y
$\sum x^{2} \quad$ : Kuadrat dari total jumlah variabel $\mathrm{x}$
$\sum y^{2} \quad$ : Kuadrat dari total jumlah variabel y
$\sum x y \quad$ : Hasil perkalian dari total jumlah variabel $\mathrm{x}$ dan variabel $\mathrm{y}$

Menentukan valid tidaknya sebuah item instrumen dengan cara membandingkan hasil $r$ hitung dengan $r$ tabel pada taraf signifikansi 5\%. Apabila $r$ hitung lebih besar sama dengan $r$ tabel maka dapat dikatakan instrumen tersebut valid. Sebaliknya, jika r hitung kurang dari sama dengan $r$ tabel maka dapat dikatakan bahwa instrumen tersebut tidak valid.

Uji reliabilitas dilakukan dengan menggunakan rumus Alpha Cronbach.

$$
r_{11}=\left(\frac{\mathrm{n}}{(\mathrm{n}-1)}\right)\left(\frac{\sigma_{t^{2}}-\sum p q}{\sigma_{t^{2}}}\right)
$$

Keterangan:

$r_{11} \quad$ : Reliabilitas yang akan dicari 


$$
\begin{array}{ll}
n & : \text { Banyaknya item } \\
\sigma_{t^{2}} & \text { : Jumlah varians skor tiap-tiap item } \\
\sum p q & \text { : Jumlah hasil perkalian antara } \mathrm{p} \text { dan } \mathrm{q}
\end{array}
$$

Teknik analisis data dengan metode komparasi konstan deskriptif (Sutama, 2019). Data hasil penilaian validator dianalisis secara diskriptif kemudian dibandingkan dengan standar yang ditetapkan. Berikut rumus yang digunakan dalam menganalisis data hasil validasi menurut Sugiyono (2012).

$$
P=\frac{f}{N} \times 100 \%
$$

\section{Keterangan:}

$$
\begin{array}{ll}
P & =\text { Skor persentase yang dicari } \\
\mathrm{f} & =\text { Perolehan skor yang diberikan } \\
N & =\text { Total skor maksimal }
\end{array}
$$

Untuk mencari rata-rata persentase penilaian kelayakan media menurut Asyhari (2016) sebagai berikut:

$$
M_{x}=\frac{\sum x}{N}
$$

\section{Keterangan:}

$M_{x} \quad=$ Rata-rata persentase penilaian yang dicari

$\sum x=$ Jumlah seluruh persentase penilaian yang diperoleh

$N \quad=$ Banyaknya persentase yang diperoleh

Kategori kelayakan yang digunakan dalam pengembangan media ini sebagai berikut.

Tabel 1. Kategori kelayakan media

\begin{tabular}{cc}
\hline Kategori & Persentase \\
\hline Sangat Layak & $81,25 \%<$ Skor $\leq 100 \%$ \\
Layak & $62,50 \%<$ Skor $\leq 81,25 \%$ \\
Kurang layak & $43,75 \%<$ Skor $\leq 62,50 \%$ \\
Tidak Layak & $25 \%<$ Skor $\leq 43,75 \%$ \\
\hline
\end{tabular}

\section{HASIL DAN PEMBAHASAN}

Media yang dikembangkan yaitu buku bergambar berbasis visual thinking strategis dengan materi pembelajaran Tema 7 Sub Tema 3 Pembelajran 5 kelas III Sekolah Dasar. Desain pengembangan berdasarkan modifikasi dari Rabiman, Nurtanto, \& Kholifah (2020) dengan analisis kebutuhan, pengembangan, implementasi dan evaluasi. Instrumen yang digunakan untuk menguji kelayakan media yang dikembangkan, sebelum digunakan validator diuji 
validitas item dan uji reliabelitas instrumen. Uji validitas dan reliabilitas dilakukan pada 30 siswa kelas 3B SD Muhammadiyah Al-Kausar Kartasura Sukoharjo Jawa Tengah. Data yang diperoleh kemudian dianalisis dengan menggunakan rumus korelasi product moment. Berikut hasil validitas yang dilakukan dengan bantuan Ms. Excel.

Tabel 2. Hasil validitas instrumen

\begin{tabular}{cccc}
\hline No soal & R Hitung & R Tabel & Keterangan \\
\hline 1 & 0,76 & 0,361 & Valid \\
2 & 0,70 & 0,361 & Valid \\
3 & 0,75 & 0,361 & Valid \\
4 & 0,55 & 0,361 & Valid \\
5 & 0,77 & 0,361 & Valid \\
6 & 0,58 & 0,361 & Valid \\
7 & 0,63 & 0,361 & Valid \\
8 & 0,55 & 0,361 & Valid \\
9 & 0,76 & 0,361 & Valid \\
10 & 0,75 & 0,361 & Valid \\
11 & 0,58 & 0,361 & Valid \\
12 & 0,72 & 0,361 & Valid \\
13 & 0,52 & 0,361 & Valid \\
\hline
\end{tabular}

Setelah dilakukan uji validitas instrumen, kemudian dilakukan uji realibilitas. Uji realibilitas pada penelitian ini menggunakan rumus Alpha Cronbach. Hasil perhitungan diperoleh nilai $\mathrm{r}$ sebesar 0,915 maka dapat dikatakan bahwa instrumen yang dibuat sangat konsisten.

Data penelitian ini yaitu hasil penilaian kelayakan media yang dikembangkan dilakukan oleh validator ahli media, ahli materi, guru, dan siswa. Hasil validasi yang dilakukan oleh ahli media berupa penilaian, saran, dan masukan terhadap media yang dikembangkan. Kemudian saran dan masukan yang diberikan oleh ahli media dijadikan pedoman dalam merevisi produk. Hasil validasi yang dilakukan oleh ahli media dapat dilihat pada gambar 1. 


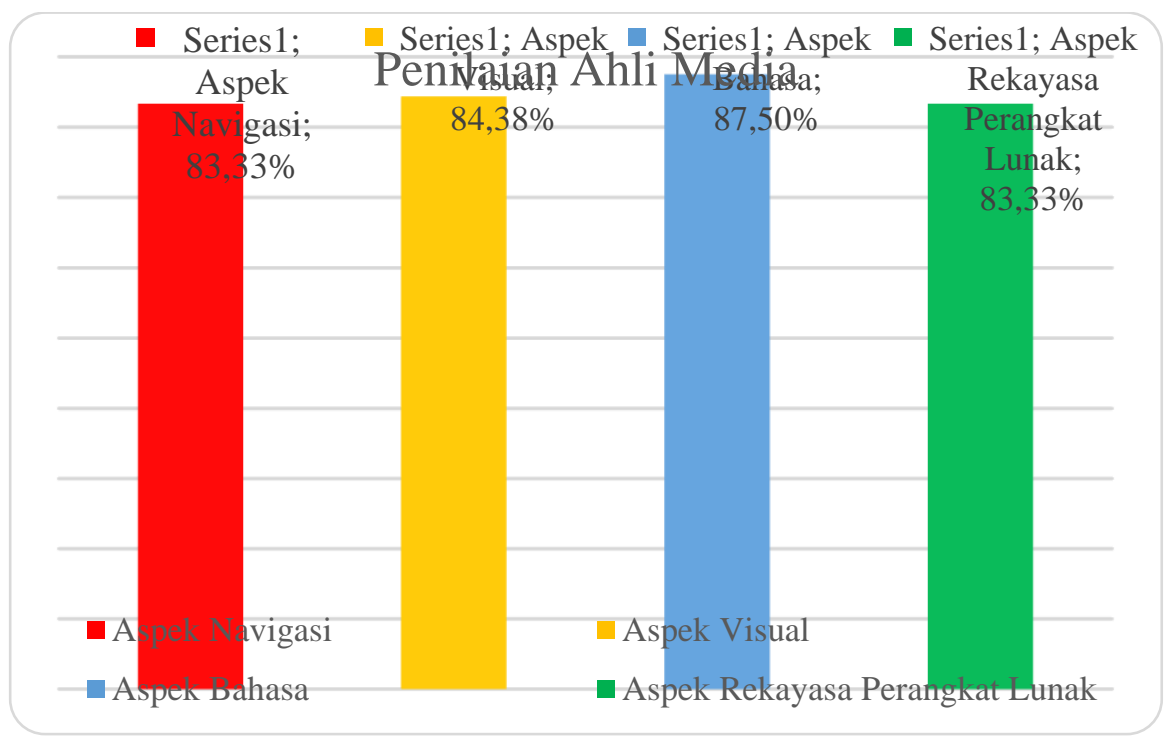

Gambar 1. Diagram batang persentase nilai dari ahli media

Gambar 1 merupakan penilaian oleh ahli media dengan perolehan persentase kelayakan ditinjau dari aspek navigasi sebesar $83,33 \%$ yang termasuk dalam kategorisangat layak. Ditinjau dari aspek visual diperoleh persentase penilaian sebesar $84,38 \%$ yang termasuk dalam kategori sangat layak. Ditinjau dari aspek bahasa diperoleh persentase penilaian sebesar 87,50\% yang termasuk dalam kategori sangat layak. Sedangkan ditinjau dari aspek rekayasa diperoleh persentase penilaian sebesar $83,33 \%$ yang termasuk dalam kategori sangat layak.

Penilaian yang dilakukan oleh ahli media tersebut, diperoleh rata-rata nilai sebesar $85 \%$, sehingga dapat disimpulkan bahwa media yang dikembangkan sangat layak digunakan sebagai media dalam pembelajaran dan pada gilirannya dapat meningkatkan hasil belajar siswa SD. Temuan ini sejalan dengan hasil penelitian yang menyatakan kepraktisan bahan ajar sangat membantu peningkatan kualitas pembelajaran tematik (Mella, Mudjiran, \& Taufina, 2019).

Validasi ahli materi dilakukan untuk memberikan penilaian terhadap kelengkapan dan kejelasan materi dalam media yang telah dibuat. Ahli materi memberikan penilaian terhadap media dari segi penyajian materi dan bahasa yang digunakan. Validasi yang dilakukan oleh ahli materi berupa penilaian, saran, dan masukan. Saran dan masukan dijadikan pedoman dalam merevisi produk dengan tujuan untuk mencapai produk yang layak. Hasil validasi yang dilakukan oleh ahli materi dapat dilihat pada gambar 2. 


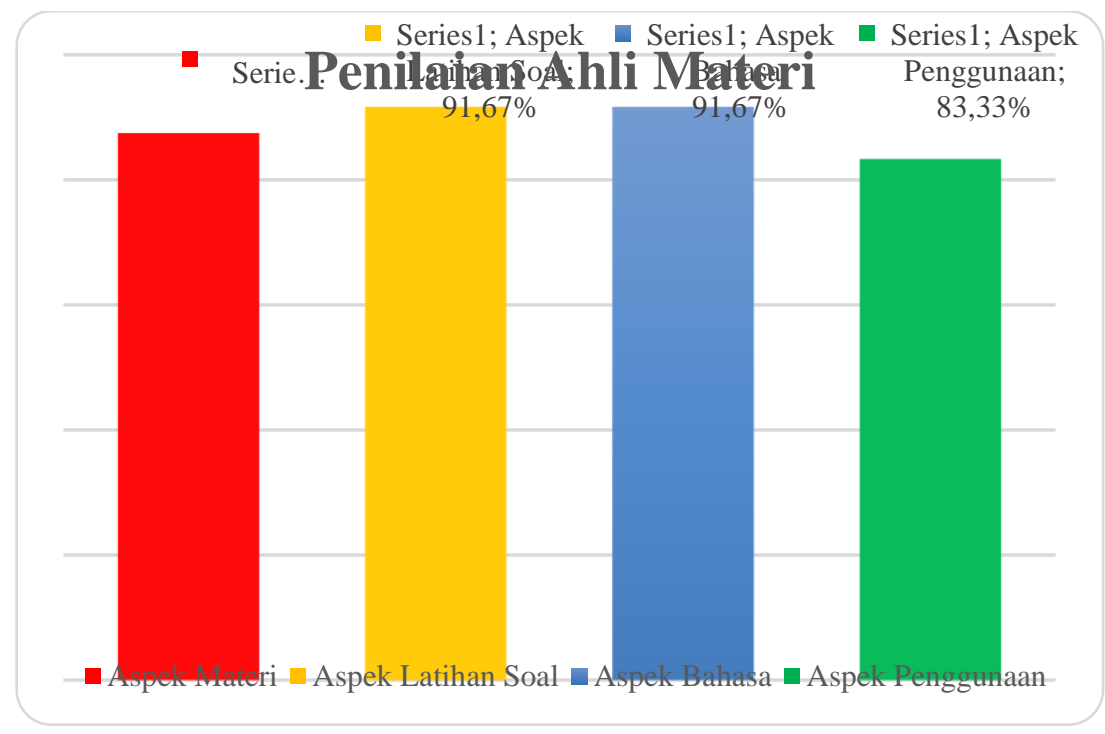

Gambar 2. Diagram batang penilaian ahli materi

Gambar 2 merupakan penilaian yang dilakukan oleh ahli materi dengan perolehan persentase kelayakan ditinjau dari aspek materi sebesar 87,50\% yang termasuk dalam kategori sangat layak. Ditinjau dari aspek latihan soal diperoleh persentase penilaian sebesar 91,67\% yang termasuk dalam kategori sangat layak. Ditinjau dari aspek bahasa diperoleh persentase penilaian sebesar $91,67 \%$ yang termasuk dalam kategori sangat layak. Sedangkan ditinjau dari aspek penggunaan diperoleh persentase penilaian sebesar $83,33 \%$ yang termasuk dalam kategori sangat layak.

Penilaian yang dilakukan oleh ahli materi diperoleh rata-rata nilai sebesar 88,75\%, sehingga dapat disimpulkan bahwa materi dalam media yang dikembangkan sangat layak digunakan dalam pembelajaran dan memuat materi yang menyenangkan serta efektif baik untuk pembelajaran luring maupun daring walaupun hanya memanfaatkan whatsapp. Hal ini senada dengan, e-learning dengan penggunaan aplikasi "whatsapp" yang berfungsi hanya sebagai tempat komunikasi antara guru dan siswa (Zhanda, Molokwane, \& Motshegwa, 2020) dapat meningkatkan komunikasi belajar.

Penilaian yang dilakukan guru SD tempat penelitian terhadap media yang telah direvisi berdasarkan saran dan masukan ahli media dan ahli materi. Penilaian ini dilakukan untuk menguji tingkat kelayakan media pembelajaran. Hasil penilaian yang dilakukan oleh guru dapat dilihat pada gambar 3 . 


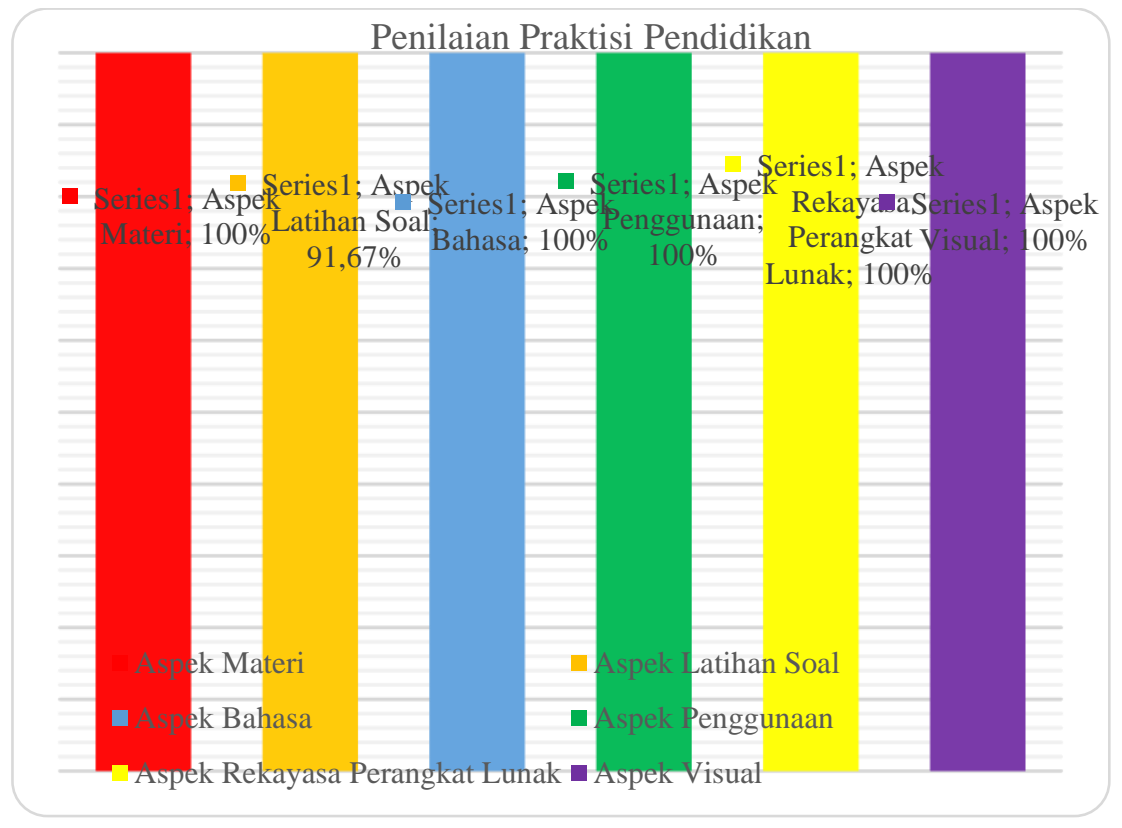

Gambar 3. Diagram batang persentase nilai dari guru

Gambar 3 merupakan penilaian yang dilakukan guru dengan perolehan persentase kelayakan ditinjau dari aspek materi sebesar $100 \%$ yang termasuk dalam kategori sangat layak. Ditinjau dari aspek latihan soal diperoleh persentase penilaian sebesar 91,67\% yang termasuk dalam kategori sangat layak. Ditinjau dari aspek bahasa diperoleh persentase penilaian sebesar $100 \%$ yang termasuk dalam kategori sangat layak. Ditinjau dari aspek pengunaan diperoleh persentase penilaian sebesar $100 \%$ yang termasuk dalam kategori sangat layak. Ditinjau dari aspek rekayasa diperoleh penilaian sebesar $100 \%$ yang termasuk dalam kategori sangat layak. Sedangkan ditinjau dari aspek visual diperoleh persentase penilaian sebesar $100 \%$ yang termasuk dalam kategori sangat layak.

Penilaian yang dilakukan guru diperoleh rata-rata sebesar 98,96\%, sehingga dapat disimpulkan bahwa media yang dikembangkan sangat layak untuk melibatkan siswa berperan aktif dalam pembelajaran tematik. Hal ini sesuai dengan hasil penelitian (Kusminah, 2012) dan (Faizah, 2009) yang menyatakan, bahwa media gambar sangat baik untuk melibatkan siswa dalam proses pembelajaran.

Uji respon siswa terhadap media yang dikembangkan dilakukan oleh 28 siswa kelas 3A SD Muhammadiyah Al-Kausar Kartasura Sukoharjo Jawa Tengah. Instrumen yang digunakan terdiri dari 3 aspek penilaian yaitu aspek rekayasa, aspek visual, dan aspek pembelajaran. Berikut hasil dari uji respon siswa. 


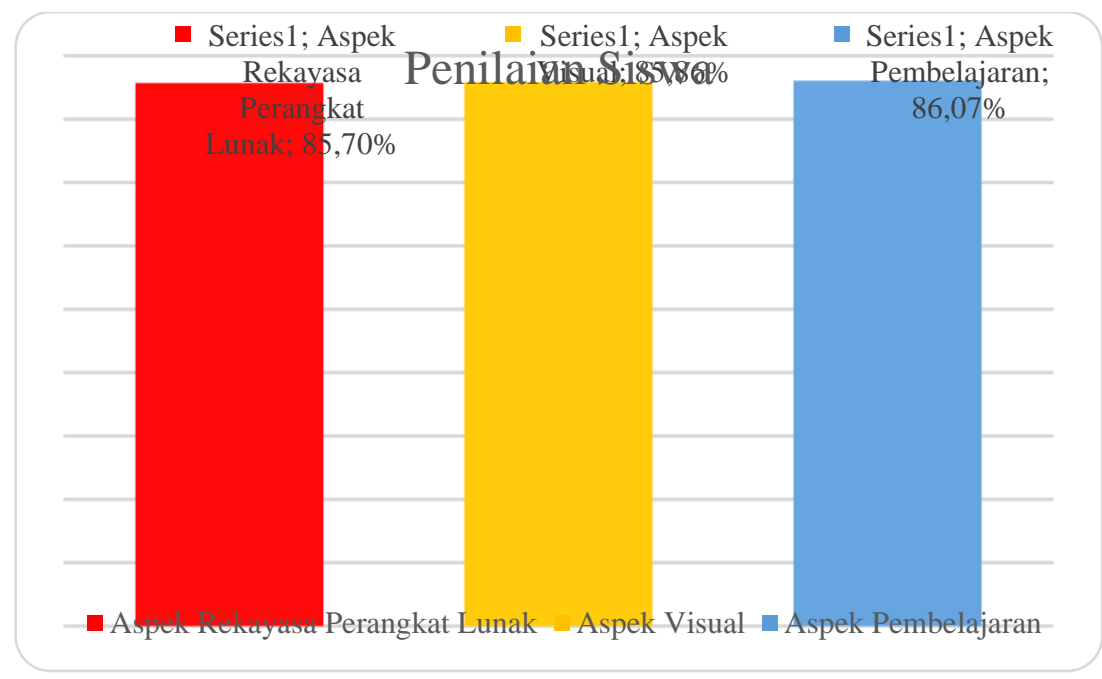

Gambar 4. Diagram batang persentase nilai respon siswa

Gambar 4 merupakan penilaian respon siswa dengan perolehan persentase kelayakan ditinjau dari aspek rekayasa sebesar $85,70 \%$ yang termasuk dalam kategori sangat layak. Ditinjau dari aspek visual diperoleh persentase nilai sebesar $85,86 \%$ yang termasuk dalam kategori sangat layak. Ditinjau dari aspek pembelajaran diperoleh persentase nilai sebesar $86,07 \%$ yang termasuk dalam kategori sangat layak.

Penilaian respon siswa diperoleh rata-rata sebesar 85,92\%, sehingga dapat dikatakan media yang dikembangkan sangat layak digunakan untuk pembelajaran di SD. Media buku bergambar berbasis visual thinking strategies, sangat layak sebagai alternatif memperkokoh rancangan pengalaman belajar tematik dalam menumbuhkembangkan berpikir kritis bagi siswa Sekolah Dasar. Hal ini didikung hasil penelitian yang menyatakan, bahwa upaya pembiasaan pengalaman belajar dapat mengembangkan kemampuan berpikir kritis (Novitasari et al., 2020; Dewi \& Haryanto, 2019), yang salah satunya melalui pemenfaatan media. Lebih lanjut pemanfaatan media dapat membiasakan guru untuk inovatif mencipkan peluang wirausaha sebagai pendidik profesional. Menurut (Katoningsih \& Sutama, 2020; Asyhari \& Silvia, 2016), sudah saatnya di era yang serba cepat ini perlu membangun program pelatihan untuk meningkatkan kewirausahaan pendidik.

Berdasarkan uraian tersebut dapat dikatakan, bahwa media yang dikembangkan dapat digunakan sebagai media pembelajaran yang layak di SD. Senada dengan hasil penelitian yang dilakukan Sudarmaji \& Khuzaini (2017), bahwa multimedia pembelajaran matematika berbasis Adobe Flash efektif digunakan dalam memfasilitasi kemampuan pemahaman konsep siswa. Hal ini didukung hasil penelitian yang menyatakan, bahwa dikarenakan dengan penerapan pembelajaran menggunakan media gambar dapat meningkatkan motivasi belajar siswa pada pembelajaran tematik di Sekolah Dasar (Ratnaningsih \& Nastiti, 2018). Begitu juga sejalan dengan simpulan hasil penelitian yang menyatakan, bahwa pembelajaran visual juga sangat sesuai diguanakan sebagai sarana mengajar di Sekolah Dasar (Buchory, 2017). ; Sáez-López, Román-González, \& Vázquez-Cano, 2016). 


\section{KESIMPULAN}

Hasil validasi media yang dikembangkan, dapat diperoleh hasil dari 1) ahli materi sebesar $88,75 \%$ termasuk dalam kategori sangat layak, 2) penilaian ahli media sebesar $85 \%$ termasuk dalam kategori sangat layak, 3) respon guru sebesar 98,75\% termasuk dalam kategori sangat layak, dan 4) respon siswa sebesar 85,92\% termasuk dalam kategori sangat layak. Berarti dapat disimpukan, media buku bergambar berbasis visual thinking strategies yang dikembangkan layak digunakan sebagai media pembelajaran di Sekolah Dasar.

Berbagai ucapan terima kasih kami sampaikan kepada berbagai pihak yang telah mendukung kegiatan penelitian ini. Ucapan terima kasih kami sampaikan kepada Direktorat Riset dan Pengabdian Masyarakat Direktorat Jenderal penguatan Riset dan Pengembangan Kementerian Riset, Teknologi, dan Pendidikan Tinggi yang telah membantu dalam pendanaan biaya penelitian mono tahun melalui Hibah Penelitian Tesis Magister. Ucapan terima kasih kami sampaikan kepada Direktur Sekolah Pascasarjana dan Ketua Lembaga Penelitian UMS beserta stafnya, yang telah memberikan fasilitas dan dorongan sehingga kami bisa melakukan penelitian. ucapan terima kasih juga kami sampaikan kepada kepala Dinas Pendidikan Sukoharjo, kepala dan guru SD Muhammadiyah Al-Kausar Kartasura Sukoharjo Jawa Tengah, yang telah membantu proses penelitian sehingga berjalan sesuai perencanaan.

\section{DAFTAR PUSTAKA}

Asyhari, A., \& Silvia, H. (2016). Pengembangan Media Pembelajaran Berupa Buletin dalam Bentuk Buku Saku untuk Pembelajran IPA Terpadu. Jurnal Ilmiah Pendidikan Fisika Al-Biruni, 5(1).

Buchory, S. R. S. W. (2017). The Development of A Learning Media for Visualizing the Pancasila Values Based on Information and Communication Technology. Cakrawala Pendidikan: Jurnal Ilmiah Pendidikan, 36(3), 502-521. https://doi.org/10.21831/cp.v36i3.12748

Burdina, G. M., Krapotkina, I. E., \& Nasyrova, L. G. (2019). Distance learning in elementary school classrooms: An emerging framework for contemporary practice. International Journal of Instruction, 12(1), 1-16. https://doi.org/10.29333/iji.2019.1211a

Dewi, S. R., \& Haryanto, H. (2019). Pengembangan multimedia interaktif penjumlahan pada bilangan bulat untuk siswa kelas IV sekolah dasar. Premiere Educandum : Jurnal Pendidikan Dasar Dan Pembelajaran, 9(1), 9.

Faizah, U. (2009). Keefektifan Cerita Bergambar untuk Pendidikan Nilai dan Ketrampilan Berbahasa dalam Pembelajaran Bahasa Indonesia. Cakrawala Pendidikan: Jurnal Ilmiah Pendidikan, 19(Hp 087834021000), 709-715. https://doi.org/10.20595/jjbf.19.0_3

Yenawine, P. (2013). Understanding Visual Literacy: The Visual Thinking Startegies Approach.

Katoningsih, S. \& Sutama. 2020. Needs analysis of potential for early childhood educators as agents of teacherpreneurship in Karanganyar. International Journal of Innovation, Creativity and Change. Volume 12, Issue 6, Pages 123-134. https://www.scopus.com/record/display.uri?eid=2-s2.085084409492\&origin=resultslist

Kusminah. (2012). The birth of the journal of educational research. Journal of Educational Research, 38(5), 321-325. https://doi.org/10.1080/00220671.1945.10881349 
Lestari, I., \& Khaeriyah, S. L. (2018). Pengaruh media pembelajaran macromedia flash terhadap kemampuan pemahaman konsep matematika. Math Didactic: Jurnal Pendidikan Matematika, 4(3), 210-219.

Mella Haniffah DP, Mudjiran, \& Taufina. (2019). Development of Understanding Reading Teaching Material as an Efforts to Improve Integrated Themat Learning Using the Big Question Strategy in Class V SD. International Journal of Science and Research (IJSR), 8(1), 1567-1570.

Muhson, A. (2010). Pengembangan Media Pembelajaran Berbasis Teknologi Informasi. Jurnal Pendidikan Akuntansi Indonesia, 8(2).

Mustika, Z. (2015). Urgenitas Media Dalam Mendukung Proses Pembelajaran Yang Kondusif. CIRCUIT: Jurnal Ilmiah Pendidikan Teknik Elektro, 1(1).

Novitasari, M., Sutama, Narimo, S., Fathoni, A., Rahmawati, L., \& Widyasari, C. 2020. Habituation of digital literacy and critical thinking in mathematics in elementary school. International Journal of Scientific and Technology Research. Volume 9, Issue 3, Pages 3395-3399. https://www.scopus.com/record/display.uri?eid=2-s2.0-85082705943\&origin=resultslist

Rabiman, R., Nurtanto, M., \& Kholifah, N. (2020). Design and development E-learning system by learning management system (Lms) in vocational education. International Journal of Scientific and Technology Research, 9(1), 1059-1063.

Ratnaningsih, S., \& Nastiti, G. (2018). Upaya Meningkatan Motivasi Belajar Siswa dengan Menggunakan Media Gambar Pada Pembelajaran Tematik di Sekolah Dasar. Al Ibtida: Jurnal Pendidikan Guru MI, 5(2), 275. https://doi.org/10.24235/al.ibtida.snj.v5i2.3397

Retnawati, H., Munadi, S., Arlinwibowo, J., Wulandari, N. F., \& Sulistyaningsih, E. (2017). Teachers' difficulties in implementing thematic teaching and learning in elementary schools. New Educational Review, 48(2), 201-212. https://doi.org/10.15804/tner.2017.48.2.16

Sudarmaji, B., \& Khuzaini, N. (2017). Pengembangan Multimedia Pembelajaran Menggunakan Adobe Flash CS3 untuk Memfasilitasi Kemampuan Pemahaman Konsep Matematika pada Siswa Kelas VIIIBMTs ASSALAFIYYAH MLANGI. PYTHAGORAS: Jurnal Program Studi Pendidikan Matematika, 6(1).

Sáez-López, J. M., Román-González, M., \& Vázquez-Cano, E. (2016). Visual programming languages integrated across the curriculum in elementary school: A two year case study using "scratch" in five schools. Computers and Education, 97, 129-141. https://doi.org/10.1016/j.compedu.2016.03.003

Sugiyono. (2012). Statistika untuk Penelitian. Bandung: Alfabeta.

Sutama, 2019. Metode Penelitian Pendidikan, Kuantitatif, kualitatif, PTK, Mix Method, R\&D. Sukoharjo: CV. Jasmine.

Zhanda, E., Molokwane, T., \& Motshegwa, B. (2020). Integrating Social Media in Teaching and Learning in Higher Education: A Quest for Collaborative Learning in Botswana. 9(4), 131-138. https://doi.org/10.21275/SR20402014354 